\title{
Synthesis, Characterization, Anti-Microbial and Anti-Cancer Activity of Novel Heterocyclic System Containing Bridgehead Nitrogen Atom
}

\author{
N.SIVASUBRAMANIAN*, M.VIKRAMADITYA REDDY, M.ARAVINDA, \\ R.SRAVANTHI and S.SIRISHA,
}

Department of Pharmaceutical Chemistry, Pulla Reddy Institute of Pharmacy, Annaram(V), Medak-Dt. Pin- 502313, India

siva_subramanian2006@rediffmail.com

Received 17 May 2012 / Accepted 4 June 2012

\begin{abstract}
Condensed quinazolines like thiadiazolo quinazolines and corresponding bioisostere thiadiazolo thienopyrimidines were found to be biologically active molecules. An attempt was made to utilize the concept of bio-isosterism for the synthesis of 3-amino2- mercapto5, 6, 7, 8-tetrahydro-benzo (b)thieno-(2,3- $d$ )-pyrimidine-4-(3H)-ones which was further treated with acetylchloride, urea, carbondisuiphide, chloroacetic acid, benzoin to affords novel fused thiadiazole, thiadiazine compounds. The novel synthesized compounds were characterized by MP, IR, ${ }^{1} \mathrm{H}$ NMR spectra. These synthesized compounds were subjected to anti-microbial studies using few gram-positive, gramnegative and fungal organisms. The standard drug used for anti-microbial activity was ampicillin and ketoconazole respectively and also tested for their anti-cancer activity by MTT assay method. The tested compounds exhibited significant antimicrobial and anti-cancer activity.
\end{abstract}

Keywords: Benzothienopyrimidines, Thiadiazoles, Thiadiazines, Anti-microbial activity, Anti- cancer activity

\section{Introduction}

Thiophene and pyrimidine derivatives have a variety of pharmacological activities ${ }^{1,2}$. Thienopyrimidines have been shown to possess a variety of pharmacological activities like anti-microbial, anti-inflammatory and anti-malarial activities ${ }^{3-5}$. Condensed quinazolines and the corresponding biostere thienopyrimidine were found to be biologically active molecules.

Therefore, it was thought of interest to utilize the concept of bio-isosterism for the synthesis of some thienopyrimidin-4-ones. The heterocyclic systems encompassing 1,3,4- thiadiazole and thiadiazine are explored to the maximum extent owing to their wide spectrum of pharmacological activities, such as fungicidal, insecticidal, bactericidal, herbicidal $^{6}$, anti-tumor ${ }^{7}$, anti-inflammatory ${ }^{8}$, anti-viral ${ }^{9}$ and CNS stimulant properties ${ }^{10}$. 
Various $\mathrm{N}$-bridged heterocycles derived from them are found to be associated with divers' pharmacological activity ${ }^{11-16}$. Prompted by the above observation and in continuation of our research for biologically active bridgehead nitrogen containing heterocycles ${ }^{17,18}$. It was decided to synthesize 1, 3, 4- thiadiazole and thiadiazine derivatives from thienopyrimidines. All the synthesized compounds have been supported by their spectral data and screened for their anti-microbial $\&$ anti-cancer activity.

\section{Experimental}

All the chemicals were obtained from Aldrich (USA), Lancaster (USA) and S.D. Fine Chem. Limited Mumbai. All the glassware is of borosilicate grade. Melting points were determined in open capillaries and are uncorrected. The purity of the compounds was ascertained by TLC on silica gel-G plate. Characterizations of synthesized compounds were done by spectral studies. IR spectra were taken in $\mathrm{KBr}$ on a SHIMADZU spectrophotometer. ${ }^{1} \mathrm{H}$ NMR spectra were recorded on BRUKER AVANCE $300 \mathrm{MHz}$ spectrophotometer in $\mathrm{CDCl}_{3}$ with TMS as internal standard. The chemical shift values are in delta ( $\mathrm{ppm}$ ). Physical data, anti-microbial, anti cancer activities data of synthesized compounds were recorded in Tables.

\section{General procedure}

\section{Step -1}

Cyclohexanone $(0.98 \mathrm{~g}, 0.01 \mathrm{~mol})$, sulphur $(0.32 \mathrm{~g}, 0.01 \mathrm{~mol})$, ethyl cyano acetate $(1.13 \mathrm{~g}$, $0.01 \mathrm{~mol})$ was added in absolute ethanol $(40 \mathrm{~mL})$ and warmed at temperature of $40-50{ }^{\circ} \mathrm{C}$. Then to this diethyl amine $4.0 \mathrm{~mL}$ was added drop wise with stirring till the sulphur dissolved in the solution. Stirring was continued for one hour till the solid (1) is separated.

\section{Step-2}

$0.05 \mathrm{~mol}$ of solid $\mathbf{1}$ in $50 \mathrm{~mL}$ of DMSO was dissolved and $3.1 \mathrm{~mL}$ of $\mathrm{CS}_{2}(0.5 \mathrm{~mol})$ was added with vigorous stirring. Stirring was continued about $30 \mathrm{~min}$. To the above mixture 10 $\mathrm{mL}$ of $2 \mathrm{M} \mathrm{NaOH}$ was with vigorous stirring. After 15 minutes $4.7 \mathrm{~mL}$ of DMS was added drop wise. After addition stirring was carried out for about $3 \mathrm{~h}$. After completion of reaction the mixture was poured in to ice-water mixture. The solid product (2) separates out.

\section{Step-3}

A solution of $(2)(3.2 \mathrm{~g}, 0.01 \mathrm{~mol})$ in isopropanol $(10 \mathrm{~mL})$ was treated with hydrazine hydrate $(99 \%, 4.3 \mathrm{~g}, 0.1 \mathrm{~mol})$ and heated under reflux on water bath until the methyl mercaptan evolution ceases. The solid (3) was obtained.

\section{Compound I}

To a solution of $\mathbf{3}(0.01 \mathrm{~mole})$ in dry pyridine $(25 \mathrm{~mL})$, the acetyl chloride $(0.01$ mole) was added drop wise. The reaction mixture was stirred at room temperature for $45 \mathrm{~min}$ and then poured into crushed ice. The solid product was obtained by filtration.

$\operatorname{IR}(\mathrm{KBr}): 1596.12 \mathrm{~cm}^{-1}(\mathrm{C}=\mathrm{O}), 1489.07 \mathrm{~cm}^{-1}(\mathrm{C}=\mathrm{N}), 2840.23 \mathrm{~cm}^{-1}\left(\mathrm{C}-\mathrm{H}\left(\mathrm{CH}_{3}\right)\right), 2986.82 \mathrm{~cm}^{-1}$ (cyclicalkanes $C$-Hstretching), $1647.24 \mathrm{~cm}^{-1}\left(\mathrm{C}=\mathrm{C}\right.$ cyloalkanes), $782.15 \mathrm{~cm}^{-1}(\mathrm{C}-\mathrm{S}){ }^{1} \mathrm{H}$ NMR $\left(\mathrm{CDCl}_{3}\right): 2.5, \mathrm{t}\left(-\mathrm{CH}_{2}-\mathrm{CH}_{2}-\mathrm{CH}_{2}-\mathrm{CH}_{2}\right) ; 1.5, \mathrm{t}\left(-\mathrm{CH}_{2}-\mathrm{CH}_{2}-\mathrm{CH}_{2}-\mathrm{CH}_{2}\right) ; 0.9, \mathrm{~s}\left(-\mathrm{CH}_{3}\right)$

\section{Compound II}

A mixture of $3(0.1$ mole $)$ and urea $(0.13$ mole $)$ was heated at $80-90{ }^{\circ} \mathrm{C}$ for $6 \mathrm{~h}$. The reaction mixture was cooled and added to a solution of $\mathrm{NaOH}(5 \%, 20 \mathrm{~mL})$ and then filtered. The filtrate was acidified with dil.HCl. The precipitated solid product was filtered. 
IR(KBr): $1596.12 \mathrm{~cm}^{-1}(\mathrm{C}=\mathrm{O}), 1575.87 \mathrm{~cm}^{-1}(\mathrm{CONH}), 3300.26 \mathrm{~cm}^{-1}$ (NH stretching), $1490.04 \mathrm{~cm}^{-1}(\mathrm{C}=\mathrm{N}), 2986.82 \mathrm{~cm}^{-1}$ (cyclicalkanes $C$-Hstretching), $1647.24 \mathrm{~cm}^{-1} \quad(\mathrm{C}=\mathrm{C}$ cyloalkanes), $782.15 \mathrm{~cm}^{-1}$ (C-S) ${ }^{1} \mathrm{H}$ NMR $\left(\mathrm{CDCl}_{3}\right): 2.5$, t $\left(-\mathrm{CH}_{2}-\mathrm{CH}_{2}-\mathrm{CH}_{2}-\mathrm{CH}_{2}\right) ; 1.5$, t $\left(-\mathrm{CH}_{2}-\right.$ $\left.\mathrm{CH}_{2}-\mathrm{CH}_{2}-\mathrm{CH}_{2}\right) ; 8.0$,s (CONH).

\section{Compound III}

A mixture of $3(0.01 \mathrm{~mol}), \mathrm{CS}_{2}(0.01 \mathrm{~mol})$ and dry pyridine $(20 \mathrm{~mL})$ was heated under reflux for $3 \mathrm{~h}$; it was cooled and poured into ice water. A solid product was obtained by filtration.

IR (KBr): $1597.09 \mathrm{~cm}^{-1}(\mathrm{C}=\mathrm{O}), 3299.30 \mathrm{~cm}^{-1}$ (NH stretching), $1249.89 \mathrm{~cm}^{-1}(\mathrm{C}=\mathrm{S})$, $1491.00 \mathrm{~cm}^{-1}(\mathrm{C}=\mathrm{N}) ; 2840.23 \mathrm{~cm}^{-1}\left(\mathrm{C}-\mathrm{H}\left(\mathrm{CH}_{3}\right)\right) ; 2986.82 \mathrm{~cm}^{-1}$ (cyclicalkanes $C$-Hstretching); $1647.24 \mathrm{~cm}^{-1}(\mathrm{C}=\mathrm{C}$ cyloalkanes $) ; 782.15 \mathrm{~cm}^{-1}(\mathrm{C}-\mathrm{S}) .{ }^{1} \mathrm{H}$ NMR $\left(\mathrm{CDCl}_{3}\right): 2.5$, t $\left(-\mathrm{CH}_{2}-\mathrm{CH}_{2}-\right.$ $\left.\mathrm{CH}_{2}-\mathrm{CH}_{2}\right) ; 1.5, \mathrm{t}\left(-\mathrm{CH}_{2}-\mathrm{CH}_{2}-\mathrm{CH}_{2}-\mathrm{CH}_{2}\right) ; 2.0, \mathrm{~s}(-\mathrm{NH})$.

\section{Compound IV}

A mixture of $3(0.01 \mathrm{~mol})$, chloroacetic acid $(0.01 \mathrm{~mol})$ and anhydrous sodium acetate $(0.01 \mathrm{~mol})$ in absolute ethanol $(50 \mathrm{~mL})$ was heated under reflux for $6 \mathrm{~h}$ and cooled in ice. The solid then separated.

IR (KBr): $1597.09 \mathrm{~cm}^{-1}(\mathrm{C}=\mathrm{O}), 1575.87 \mathrm{~cm}^{-1}(\mathrm{CONH}), 3300.26 \mathrm{~cm}^{-1} \mathrm{NH}$ (stretching), $1491.00 \mathrm{~cm}^{-1}(\mathrm{C}=\mathrm{N}), 2985.86 \mathrm{~cm}^{-1} \quad$ (Cyclic alkanes C-H stretching), $1647.24 \mathrm{~cm}^{-1}$ (Cycloalkenes $\mathrm{C}=\mathrm{C}), 782.15 \mathrm{~cm}^{-1}(\mathrm{C}-\mathrm{S}){ }^{1} \mathrm{H}$ NMR $\left(\mathrm{CDCl}_{3}\right): 2.5, \mathrm{t}\left(-\mathrm{CH}_{2}-\mathrm{CH}_{2}-\mathrm{CH}_{2}-\mathrm{CH}_{2}\right) ; 1.5, \mathrm{t}$ $\left(-\mathrm{CH}_{2}-\mathrm{CH}_{2}-\mathrm{CH}_{2}-\mathrm{CH}_{2}\right) ; 8.0, \mathrm{~s}(\mathrm{CO}-\mathrm{NH}) ; 3.76, \mathrm{~s}\left(\mathrm{C}-\mathrm{CH}_{2} \mathrm{~S}\right)$.

\section{Compound V}

A mixture of $3(0.005 \mathrm{~mol})$, benzoin $(0.005 \mathrm{~mol})$ in absolute ethanol $(50 \mathrm{~mL})$ was heated to get a clear solution and to the hot solution $2 \mathrm{~N} \mathrm{KOH}(1 \mathrm{~mL})$ was added. The resulting mixture was refluxed with constant stirring for about half an hour, the yellow precipitate was obtained.

IR (KBr): $1596.12 \mathrm{~cm}^{-1}(\mathrm{C}=\mathrm{O}) ; 3299.30 \mathrm{~cm}^{-1}\left(\mathrm{NH}\right.$ stretching); $3020 \mathrm{~cm}^{-1}(\mathrm{C}-\mathrm{H}$ aromatic); $1490.04 \mathrm{~cm}^{-1}(\mathrm{C}=\mathrm{N}) ; 2986.82 \mathrm{~cm}^{-1}$ (Cyclic alkanes $\mathrm{C}-\mathrm{H}$ stretching); $1645.31 \mathrm{~cm}^{-1}$ (Cycloalkenes $\mathrm{C}=\mathrm{C}) ; 782.15 \mathrm{~cm}^{-1}$ (C-S) ${ }^{1} \mathrm{H}$ NMR $\left(\mathrm{CDCl}_{3}\right): 2.5$, $\mathrm{t}\left(-\mathrm{CH}_{2}-\mathrm{CH}_{2}-\mathrm{CH}_{2}-\mathrm{CH}_{2}\right) ; 1.5, \mathrm{t}$ $\left(-\mathrm{CH}_{2}-\mathrm{CH}_{2}-\mathrm{CH}_{2}-\mathrm{CH}_{2}\right) ; 2.0, \mathrm{~s}(-\mathrm{NH}) ; 7.2-7.8$, $\mathrm{m}(-\mathrm{Ar}-\mathrm{H})$

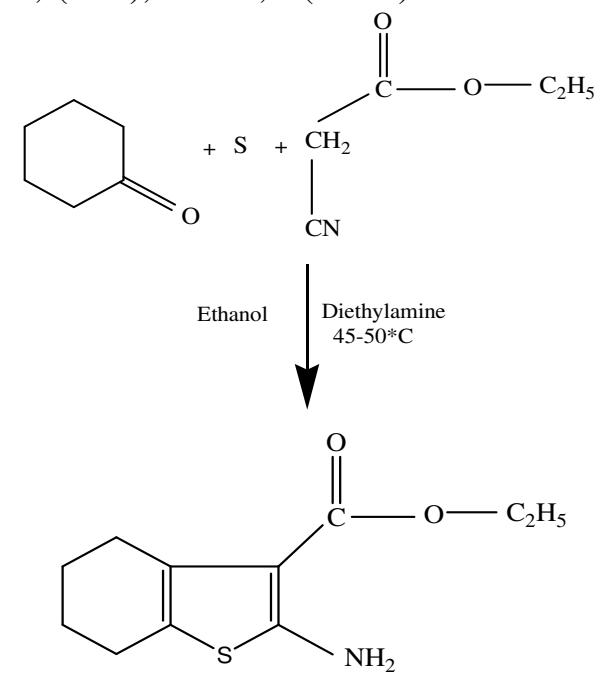




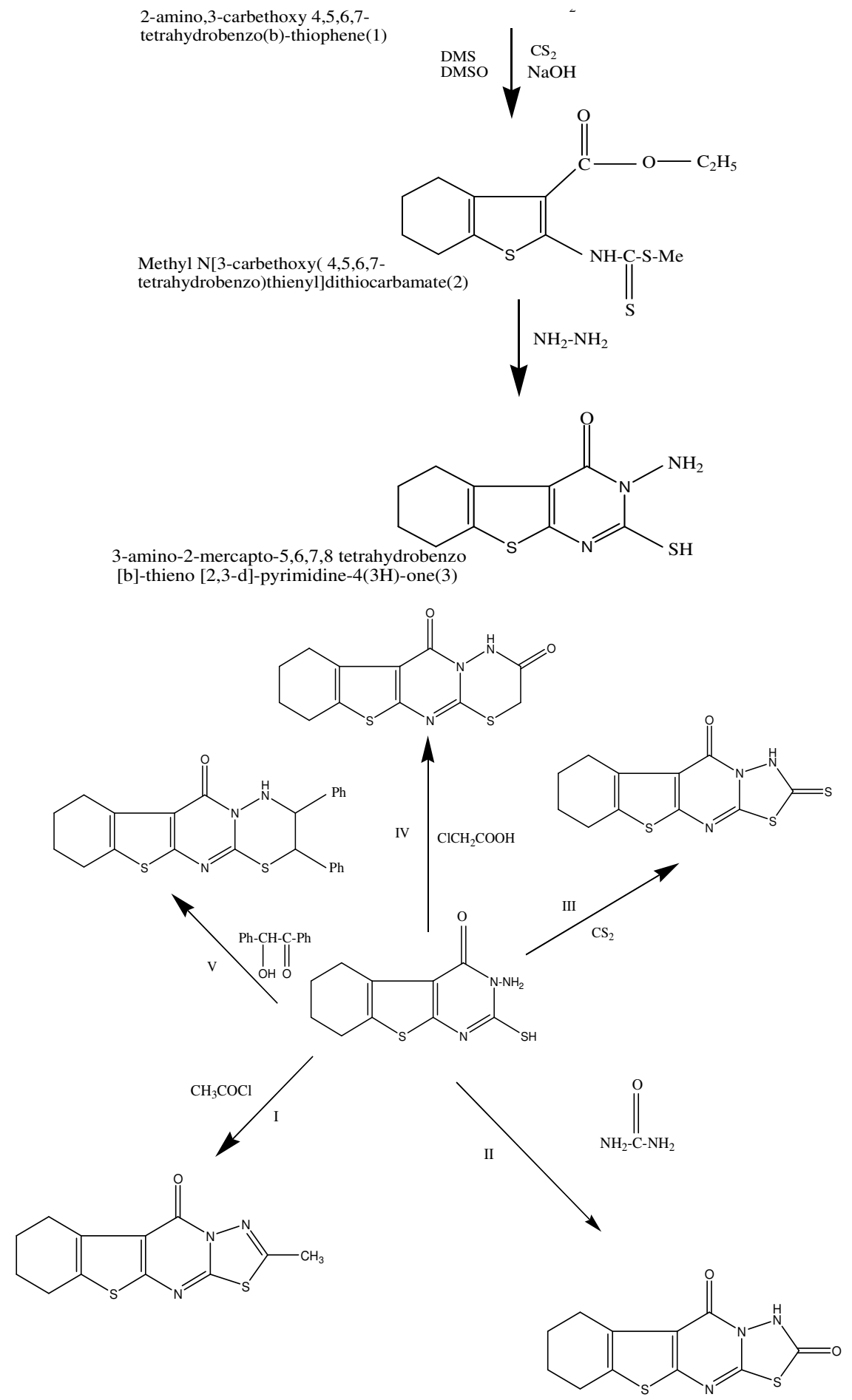

Scheme 1 


\section{Invitro anti-microbial activity ${ }^{19,20}$}

The synthesized compounds were reconstituted in dimethyl formamide (DMF) as this does not demonstrate any anti bacterial activity by itself. Initially, a suspension of nutrient agar medium was prepared. These suspension medium was then inoculated by $100 \mu \mathrm{L}$ of Staphylococcus aureous ATCC9144 organism and the inoculation was possible only at $50{ }^{\circ} \mathrm{C}$. Below this temperature the suspension of agar medium gets solidified and hence uniform distribution of test organism cannot be achieved. Then immediately pour the inoculated agar medium into a sterile Petridish under aseptic conditions. Maintenance of aseptic condition is an essential factor, which does not allow the contamination of other microorganism. Now the petridishes are kept aside for few minutes, in order to get solidified, forming a thin uniform layer of about 2-4 mm. sterile discs made up of whatmann paper are used to apply the standard and test solutions on to the culture media. Initially the discs are socked in control, standard drugs (Ampicillin \& Ketoconazole) and test solutions separately and then, place on inoculated culture medium aseptically. Fine distance should be kept between these discs. Petridishes are tightly packed and subjected to incubation at $37{ }^{\circ} \mathrm{C}$ to $40{ }^{\circ} \mathrm{C}$ for $48 \mathrm{~h}$. Bacterial growth inhibition was determined as the diameter of inhibition zones around the disc. All tests were performed in triplicates. The resultant clear zones were measured in millimeters (mms) and compared against standard. Similar procedure carried out by using following organisms Micrococcus luteus ATCC25923, Staphylococcus epidermidis ATCC10987, Klebsiella pneumonia ATCC29212, Escherichia coli ATCC25922, Candida albicans ATCC 2091 and Aspergillus niger ATCC 9029.

\section{In vitro anti-cancer activity}

MTT [(3-(4,5-dimethylthiazol-2yl)-2,5-diphenyltetrazoliumbromide] assay ${ }^{21}: 0.1 \mathrm{~mL}$ of the cell suspension (containing $5 \times 10^{6}$ cells $/ 100 \mu \mathrm{L}$ ) and $0.1 \mathrm{~mL}$ of the test solution $(6.25 \mu \mathrm{g}-$ $100 \mu \mathrm{g}$ in $1 \%$ DMSO such that the final concentration of DMSO in media is less than $1 \%$ ) were added to the 96 well plates and kept in $5 \% \mathrm{CO}_{2}$ incubator at $37{ }^{\circ} \mathrm{C}$ for 72 hours. Blank contains only cell suspension and control wells contain $1 \%$ DMSO and cell suspension. After 72 hours, $20 \mu \mathrm{L}$ of MTT was added and kept in carbondioxide incubator for 2 hours followed by propanol $100 \mu \mathrm{L}$. The plate was covered with aluminum foil to protect it from light. Then the 96 well plates are kept in rotary shaker for 10-20 minutes.

After 10-20 minutes, the 96 well plates were processed on ELISA reader for absorption at $562 \mathrm{~nm}$. The readings were averaged and viability of the test samples was compared with DMSO control. The percentage growth inhibition was calculated using the following formula

$$
\% \text { Growth Inhibition }=100-\text { Abs }(\text { Sample }) / \text { Abs (Control) } X 100
$$

The final results are in $\mathrm{GI}_{50}$ (growth inhibition 50), TGI (total growth inhibition), $\mathrm{LC}_{50}$ (lethal concentration 50). The cell lines used were HT29-Colon cancer, Hela-Cervical, HepG2-Liver cancer.

\section{Results and Discussion}

The synthesized compounds of the present study were characterized through IR \& ${ }^{1} \mathrm{H}$ NMR spectra. In the IR spectra of the 3-amino2-mercapto-5,6,7,8-tetrahydrobenzo[b]thieno[2,3- $d]$ pyrimidine-4 $(3 H)$ one the characteristic $-\mathrm{NH}_{2}$ and $\mathrm{SH}$ bands appeared in the region of 1340 $1250 \mathrm{~cm}^{-1}$ and $2600-2550 \mathrm{~cm}^{-1}$ respectively. The strong bands at $3500-3220 \mathrm{~cm}^{-1}$ corresponding to initial $\mathrm{NH}_{2}$ were absent, which was the most characteristic evidence of the cyclocondensation. 
In the ${ }^{1} \mathrm{H}$ NMR spectra of the 3-amino2-mercapto-5,6,7,8-tetrahydrobenzo[b]thieno $[2,3-d]$ pyrimidine- $4(3 H)$ one the characteristic $-\mathrm{NH}_{2}$ and $\mathrm{SH}$ peaks appeared in the region of 2.0 and 1.5 respectively. The peaks at 8.0 corresponding to initial $\mathrm{NH}_{2}$ were absent and also there are no peaks for thiol proton, which was the most characteristic evidence of the cyclocondensation.

All the synthesized compounds in the present study showed significant activity against microbs when compared with that of ampicillin and ketoconazole as standards. The zone of inhibition at 25,50 and $100 \mu \mathrm{g} / \mathrm{mL}$ concentrations of synthesized compounds against grampositive, gram-negative bacteria and fungi are measured by disc diffusion methods. The zone of inhibition of synthesized compounds was found similar to that of standards at $100 \mu \mathrm{g} / \mathrm{mL}$ conc. Results summarizes in Tables $2-6$ respectively.

Table 1. Physical data of synthesized compounds

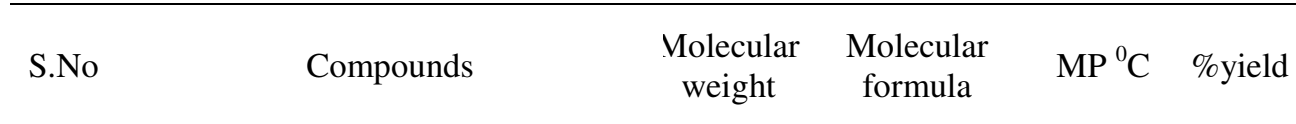

I<smiles>Cc1nn2c(=O)c3c4c(sc3nc2s1)CCCC4</smiles>

II.<smiles>O=c1[nH]n2c(=O)c3c4c(sc3nc2s1)CCCC4</smiles>

III.<smiles>O=c1c2c3c(sc2nc2sc(=S)[nH]n12)CCCC3</smiles>

IV.<smiles>O=C1CSc2nc3sc4c(c3c(=O)n2N1)CCCC4</smiles>

V.<smiles>O=c1c2c3c4sc2nc(n1NC(c1ccccc1)C(c1ccccc1)S3)CCCC4</smiles>

277.37<smiles>[Mg][Mg][Mg]</smiles>

$63-74^{0}$

$82 \%$

279.34

$\mathrm{C}_{11} \mathrm{H}_{9} \mathrm{~N}_{3} \mathrm{O}_{2} \mathrm{~S}_{2} \quad 140-150^{0}$

$72 \%$

295.4

$\mathrm{C}_{11} \mathrm{H}_{9} \mathrm{~N}_{3} \mathrm{OS}_{3} \quad 90-100^{0}$

$67 \%$

293.36

$\mathrm{C}_{12} \mathrm{H}_{11} \mathrm{~N}_{3} \mathrm{O}_{2} \mathrm{~S}_{2} \quad 75-80^{0}$

$80 \%$

431.57 
Table 2. Zone of inhibition of $25 \mu \mathrm{g} / \mathrm{mL}$ concentration of synthesized compounds against $\operatorname{gram}(+)$ ve and gram (-)ve bacteria

\begin{tabular}{|c|c|c|c|c|c|c|}
\hline \multirow[b]{2}{*}{$\begin{array}{l}0 \\
\dot{z} \\
\dot{n}\end{array}$} & \multirow[b]{2}{*}{ 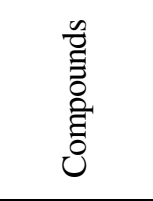 } & \multicolumn{5}{|c|}{ Zone of inhibition in $\mathrm{mm}$} \\
\hline & & $\begin{array}{c}\text { Staphylococcus } \\
\text { aureus } \\
\text { ATCC9144 }\end{array}$ & $\begin{array}{c}\text { micr } \\
\text { Staphylococcus } \\
\text { epidermidis } \\
\text { ATCC10987 }\end{array}$ & $\begin{array}{l}\text { roorganisms } \\
\text { Micrococcus } \\
\text { luteus } \\
\text { ATCC } 11778\end{array}$ & $\begin{array}{c}\text { Klebsiella } \\
\text { pneumonia } \\
\text { 3 ATCC29212 }\end{array}$ & $\begin{array}{c}\text { Escherichia } \\
\text { coli mutant } \\
\text { ATCC } 25922\end{array}$ \\
\hline 1 & I & 4 & 5 & 5 & 4 & 5 \\
\hline 2 & II & 5 & 4 & 5 & 5 & 4 \\
\hline 3 & III & 6 & 5 & 4 & 5 & 4 \\
\hline 4 & IV & 5 & 5 & 4 & 5 & 6 \\
\hline 5 & $\mathrm{~V}$ & 5 & 4 & 5 & 5 & 4 \\
\hline 6 & $\begin{array}{c}\text { Standard } \\
10 \mu \mathrm{g} / \mathrm{mL}\end{array}$ & 17 & 18 & 17 & 17 & 18 \\
\hline 7 & Control & - & - & - & - & - \\
\hline
\end{tabular}

Table 3. Zone of inhibition of $50 \mu \mathrm{g} / \mathrm{mL}$ concentration of synthesized compounds against gram(+) ve and gram (-)ve bacteria

\begin{tabular}{|c|c|c|c|c|c|c|}
\hline \multirow[b]{3}{*}{$\begin{array}{l}\stackrel{\circ}{z} \\
\text { is }\end{array}$} & \multirow{3}{*}{ 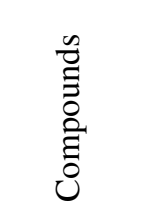 } & \multicolumn{5}{|c|}{ Zone of inhibition in $\mathrm{mm}$} \\
\hline & & \multicolumn{5}{|c|}{ microorganisms } \\
\hline & & $\begin{array}{c}\text { Staphylococcus } \\
\text { aureus } \\
\text { ATCC9144 }\end{array}$ & $\begin{array}{c}\text { Staphylococcus } \\
\text { epidermidis } \\
\text { ATCC10987 }\end{array}$ & $\begin{array}{c}\text { Micrococcus } \\
\text { luteus } \\
\text { ATCC } 11778\end{array}$ & $\begin{array}{c}\text { Klebsiella } \\
\text { pneumonia } \\
\text { ATCC29212 }\end{array}$ & $\begin{array}{l}\text { Escherichia } \\
\text { coli mutant } \\
\text { ATCC } 25922\end{array}$ \\
\hline 1 & I & 11 & 11 & 10 & 10 & 10 \\
\hline 2 & II & 10 & 12 & 11 & 11 & 11 \\
\hline 3 & III & 12 & 12 & 10 & 10 & 10 \\
\hline 4 & IV & 12 & 12 & 10 & 10 & 9 \\
\hline 5 & V & 13 & 11 & 10 & 9 & 10 \\
\hline 6 & $\begin{array}{c}\text { Standard } \\
10 \mu \mathrm{g} / \mathrm{mL}\end{array}$ & 17 & 18 & 17 & 17 & 18 \\
\hline 7 & Control & - & - & - & - & - \\
\hline
\end{tabular}

Table 4. Zone of inhibition of $100 \mu \mathrm{g} / \mathrm{mL}$ concentration of synthesized compounds against $\operatorname{gram}(+)$ ve and gram (-)ve bacteria

\begin{tabular}{|c|c|c|c|c|c|c|}
\hline \multirow[b]{3}{*}{$\begin{array}{l}\stackrel{0}{z} \\
\dot{n}\end{array}$} & \multirow{3}{*}{$\begin{array}{l}\tilde{z} \\
\bar{\Xi} \\
\overline{0} \\
\tilde{\Xi}\end{array}$} & \multicolumn{5}{|c|}{ Zone of inhibition in $\mathrm{mm}$} \\
\hline & & \multicolumn{5}{|c|}{ microorganisms } \\
\hline & & $\begin{array}{c}\text { Staphylococcus } \\
\text { aureus } \\
\text { ATCC } 9144\end{array}$ & $\begin{array}{c}\text { Staphylococcus } \\
\text { epidermidis } \\
\text { ATCC10987 }\end{array}$ & $\begin{array}{c}\text { Micrococcus } \\
\text { luteus } \\
\text { ATCC } 11778\end{array}$ & $\begin{array}{c}\text { Klebsiella } \\
\text { pneumonia } \\
\text { ATCC29212 }\end{array}$ & $\begin{array}{l}\text { Escherichia } \\
\text { coli mutant } \\
\text { ATCC25922 }\end{array}$ \\
\hline 1 & I & 13 & 12 & 13 & 14 & 13 \\
\hline 2 & II & 12 & 13 & 14 & 15 & 14 \\
\hline 3 & III & 13 & 14 & 13 & 14 & 13 \\
\hline 4 & IV & 14 & 14 & 13 & 14 & 13 \\
\hline 5 & $\mathrm{~V}$ & 14 & 13 & 14 & 14 & 13 \\
\hline 6 & $\begin{array}{c}\text { Standard } \\
10 \mu \mathrm{g} / \mathrm{mL}\end{array}$ & 17 & 18 & 17 & 17 & 18 \\
\hline 7 & Control & - & - & - & - & - \\
\hline
\end{tabular}


Table 5. Zone of inhibition of synthesized compounds against Candida albicans

\begin{tabular}{ccccc}
\hline \multirow{2}{*}{ S.No } & Compounds & \multicolumn{3}{c}{ Zone of inhibition in mm } \\
\cline { 3 - 5 } & & 25 & 50 & 100 \\
\cline { 3 - 5 } 1 & I & 10 & 14 & 17 \\
2 & II & 9 & 12 & 16 \\
3 & III & 9 & 13 & 17 \\
4 & IV & 8 & 12 & 16 \\
5 & V & 9 & 12 & 17 \\
6 & Standard & 16 & 18 & 18 \\
7 & $10 \mu \mathrm{g} / \mathrm{mL}$ & - & - & - \\
\hline
\end{tabular}

Table 6. Zone of inhibition of synthesized compounds against aspergillus niger

\begin{tabular}{ccccc}
\hline \multirow{2}{*}{ S.No } & Compounds & \multicolumn{3}{c}{ Zone of inhibition in mm } \\
\cline { 3 - 5 } & & 25 & 50 & 100 \\
\cline { 3 - 5 } & I & 9 & 13 & 18 \\
2 & II & 8 & 11 & 19 \\
3 & III & 8 & 14 & 18 \\
4 & IV & 8 & 14 & 18 \\
5 & V & 9 & 13 & 19 \\
6 & Standard & 20 & 19 & 20 \\
7 & $10 \mu \mathrm{g} / \mathrm{mL}$ & - & - & - \\
\hline
\end{tabular}

The cytotoxicity studies of the synthesized compounds were evaluated against human cell lines. (colon, cervical and liver). The compounds were found to exhibit moderate cytotoxicity activities in all cell lines. Compound I shows significant anti-cancer activity in all cell lines. Synthesized compounds II, IV and V were found to exhibit mild cytotoxic in all cell lines. In toxicity wise compound I is lesser than the compound III. The cytotoxicity data of the synthesized compounds were evaluated against human cell lines summarizes in Table 7.

Table 7. Anti-cancer data of synthesized compounds

\begin{tabular}{cccccccccc}
\hline \multirow{2}{*}{ Sample } & \multicolumn{3}{c}{ HT29 } & \multicolumn{3}{c}{ HepG2 } & \multicolumn{3}{c}{ Hela } \\
\cline { 2 - 9 } & $\mathrm{GI}_{50}$ & TGI & LC $_{50}$ & GI $_{50}$ & TGI & LC $_{50}$ & GI $_{50}$ & TGI & LC $_{50}$ \\
\hline I & 22.8 & 49.5 & $>100$ & 15.5 & 46.6 & 91.5 & 22.1 & 48.8 & 79.2 \\
II & 25.2 & 55.5 & 91.6 & 22.5 & 47.6 & 98.0 & 32.6 & 71.0 & $>100$ \\
III & 18.3 & 29.5 & 68.0 & 18.4 & 43.8 & 81.0 & 29.7 & 63.7 & $>100$ \\
IV & 25.2 & 58.5 & 98.7 & 27.7 & 48.0 & 97.7 & 31.3 & 75.5 & $>100$ \\
V & 22.5 & 63.5 & $>100$ & 41.6 & 61.9 & $>100$ & 26.8 & 61.7 & $>100$ \\
\hline
\end{tabular}

\section{Conclusion}

In the present study novel benzothieno pyrimidines fused with thiadiazines and thiadiazoles were synthesized. The synthesized compounds were characterized by IR, ${ }^{1} \mathrm{H}$ NMR spectrum. All the synthesized compounds showed characteristic absorption peaks in IR and ${ }^{1} \mathrm{H}$ NMR spectra. 
The synthesized compounds were subjected to in vitro anti-microbial evaluation. The zone of inhibition at various concentrations of synthesized compounds against grampositive, gram-negative bacteria and fungi are measured by disc diffusion methods. The anti-microbial studies revealed that all the benzothieno pyrimidine derivatives showed significant activity when compared with that of standard at $100 \mu \mathrm{g} / \mathrm{mL}$ conc.

The cytotoxicity studies of the synthesized compounds were evaluated against human cell lines (colon, cervical and liver). Synthesized compounds were found to exhibit moderate cytotoxicity activities in all cell lines. Therefore further studies required for biologically more potent compounds in these series.

\section{Acknowledgement}

The authors are thankful to Chairman, Principal, Pullareddy Institute of Pharmacy for giving the required facilities for carrying out synthetic work and also thankful to Dr.Reddy's, IICT Hyderabad, for providing spectral data.

\section{References}

1. Hagen Helmut, Becke Friedrich, Chem Abstr., 1971, 74, 88033z.

2. Takamizawa, Chem Abstr., 1971, 74, 88038e.

3. Nitinkumar S Shetty, Ravi S Lamanil, Imtiyaz Ahmed and Khazi M, J Chem Sci., 2009, 121, 301-307

4. Nabil H, Ouf Abd El- Galil E, Amr Monatshefte Fur Chemie, 2008, 139, 579-585.

5. Rosowsky A, Chen K K N and M Lin M, J Med Chem., 1973, 16(3), 191-194.

6. Kurtzer F, Katritzky A R and Boulton A J, Advances in Heterocyclic Chemistry: Academic Press, New York, 1965, 5, 165.

7. Shivarama Holla B, Narayana Poojary K, Sooryanarayana Rao B and Shivananda M K, Eur J Med Chem., 2002, 37, 511-517.

8. $\quad$ Cooper K and Steele J, EP 329357: Chem Abstr., 1990, 112, 76957.

9. Todoulou O G, Papadaki- Valiraki A E, Ikeda S and De Clercq E, Eur J Med Chem., 1994, 29, 611

10. Heindel N D and Reid J R, J Heterocycl Chem., 1980, 17, 1087.

11. Walser A, Flyman T and Musan C, J Het Chem., 1991, 28, 1121.

12. Hitora T, Sajaki K, Yumamota H and Nakayama T, J Het Chem., 1991, 28, 257

13. Kane J M, Barton B M, Dudley M W, Sorenson S M and Stueger M A, J Med Chem., 1990, 33, 2772.

14. Bardbury R H and Rivert J E, J Med Chem., 1991, 34,151.

15. Kumamoto T, Toyooka K, Nishida M and Kubota S, Chem Pharm Bull, 1990, 38, 2595.

16. Ashour P F A and Almazora S A H, Farmaco, 1990, 45, 1207.

17. Sivasubramanian N and Omprakash G, Int J Chem Sci., 2010, 8(2), 783-790.

18. Sivasubramanian N and Omprakash G, Int J Chem Sci., 2010, 8(3), 1871-1877

19. Collee J.G, Fraster A.G and Marimion B.P, Practical Medical Microbiology: $13^{\text {th }}$ Ed., Churchill living stone, London 1989, 163-165.

20. Ananthanarayanan R and Panikr J.C.K, Text book of microbiology: $5^{\text {th }}$ Ed., Orient Longman Ltd, 1987, 620-621.

21. Scudiero D A, shoemaker R H and Paul K D, Monks A, Tierney S, Nofziger T H, Currens M J, Seniff D and Boyd M R, Cancer Res., 1988, 48, 4827-4833. 